\title{
Physiological Studies On The Efficacy Of Silymarin As Antioxidant Against The Disorders In Some Blood Constituents Induced By Irradiation In Female Rats.
}

\author{
Mohamed S. El-Gabry*, Hekmat M. Abou-Safi **, Nabil A. El-Yamany* \\ and Gehan R. Abdel-Hamid**. \\ * Zoology Dept., Faculty of Science, Helwan University. \\ ** Radiation Biology Dept., National Center for Radiation Research and \\ Technology (NCRRT), P.O. Box 29 Nasr City, Cairo.
}

This work was directed to evaluate the possible role of silymarin (a flavonoid used as antihepatoxic agent) as a prophylactic agent confronting radiation hazard. Eighty female albino rats were selected at the estrous stage and divided into four groups (G1 G4): 1- Control. 2- Whole body $\gamma$-irradiated group with two doses 1 Gy and 6 Gy. 3- Silymarin orally administered group (10 mg / $100 \mathrm{~g} \mathrm{~b}$. wt., twice daily for one week with the last dose 2 hours before blood sampling). 4- Silymarin administered as G3 then rats were irradiated after 2 hours. Blood samples were taken at 2 hours, 2 days and 2 weeks after the last silymarin dose (G3) or irradiation (G2 and G4).

Irradiation induced significant declines in RBCs and WBCs count, $\mathrm{Hg}$ content and Hct \% denoting a deleterious effect in a dose and time dependent manner. Yet, it produced high levels of plasma malondialdehyde, as the end product of lipid peroxidation, concomitant with reduced levels of blood glutathione indicating a depression in the antioxidant system. Dramatic increments in the plasma indices of liver (ALT, AST and alkaline phosphatase) and kidney (urea, uric acid and creatinine) functions were also recorded depicting a liver and kidney impairment state. Silymarin manifested good amelioration in the radiation-induced changes in the studied parameters. Hence, it could be concluded that silymarin plays a beneficial radioprotective role against radiation hazard in female rats which serves a great sector of women working in radiation application fields or those undergoing radiotherapy.

\section{Introd uction}

Exposure to ionizing radiation could induce direct and /or indirect effect in the biological system. The depth of penetration of an ionizing radiation depends on the nature of the radiation on one hand and on the composition and density of irradiated substance on the other (Yarmonenko, 1988).

Ionizing radiation injury to living cells is to a large extent, due to induction of free radicals and oxidative stress (Karbownik and Reiter, 2000).

There has been a substantial increase in the use of complementary therapies by patients to manifest the oxidative stress. Although many such modalities are available, herbal thera pies are the most popular, and one of these remedies is Silymarin (Bass, 1999). Silymarin (milk thistle) is a mixture of flavonolignans, comprised mainly of three isomers: silybin, silydianin and silychristin extracted from the seeds and fruits of silybum marianum (Quaglia et al., 1999). It has been clinically used largely as an antihepatoxic agent, due to its strong antioxidant activity (Lahiri - Chatterjee 
et al., 1999). The present investigation has been carried out to study:

1.The hazard effects of exposure to whole-body $\gamma$-irradiation on the level of blood glutathione (GSH) as a free radical scavenger, plasma malondialdehyde (MDA) as the main product of lipid peroxidation, some haematological parameters, liver function indices (plasma AST, ALT and alkaline phosphatase), and kidney function indices (plasma urea, uric acid and creatinine) in female rats.

2.The possible prophylactic role of silymarin in confronting $\gamma$ irradiation sickness.

3.The evaluation of both the early and delayed effects of $\gamma$-radiation at the low and high doses.

\section{Material and Methods}

In this study eighty adult female albino rats weighted about $150 \pm 50 \mathrm{~g}$ were used. They were obtained from the animal house of the Biological Applications Dept., Nuclear Research Center, Inshas. Rats were housed in plastic cages, under normal temperature, pressure, humidity and good ventilation and illumination conditions, watered and fed with access of standard granulated chow.

All females were selected at the oestrus stage. Cycle stages were assessed by daily inspection of vaginal smear cytology.

Experimental design:

Animals were categorized into four main groups as follows:

1- Control group (5 rats).

2- Whole body gamma irradiated group (30 rats) subdivided into two subgroups: A- irradiated with 1 Gy. B- irradiated with 6 Gy.

3 - Silymarin injected group (15 rats).

4 - Silymarin injected then irradiated group (30 rats) subdivided into two subgroups similar to group (2).

\section{Treatments:}

1- Irradiation: Whole-body gamma irradiation at two dose levels $1 \mathrm{~Gy}$ and a sub-lethal dose 6 Gy (groups 2 and 4) was performed using a ventilated Cesium -137 Gamma Cell-40 manufa ctured by the Atomic Energy of Canada Limited (AECL) belonging to the NCRRT. The unit provides a mean for uniform gamma irradiation of small animals at a dose rate $1 \mathrm{~Gy} / 1.2 \mathrm{~min}$. at the experimentation time.

2- Silymarin Injection: Animals of both groups three and four were administered orally with silymarin produced by South Egypt Drug Industries company (SEDICO) at a dose level $10 \mathrm{mg} / 100 \mathrm{~g}$ body weight dissolved in distilled water. Silymarin was injected twice daily for one week with the last injection two hours before blood sampling (group 3) and two hours pre-irradiation (group 4).

\section{Blood sampling and time intervals:}

All animals were anaesthetized with chloroform and blood samples were collected by heart puncture in centrifuge tubes containing EDTA at three time intervals: two hours, two days and two weeks after the last silymarin dose injection (group 3) or after irradiation (group two and four). A part of fresh blood samples was used for the investigation of blood picture parameters (haemoglobin, haematocrit $\%$, total erythrocytic count and total leucocytic count) according to Dacie and Lewis (1991), and for the determination of blood glutathione content according to Beutler et al. (1963). The second part of blood was centrifuged and the separated plasma was used for the evaluation of malondialdehyde according to Yoshioka et al. (1979) and the determination of liver function (ALT, AST and alkaline phosphatase) and kidney function (urea, 
uric acid and creatinine) indices using biochemical kits manufactured by Diamond Diagnostic (Egypt) and Biocon (Germany) companies.

Comparison of the means and statistical analysis were performed using paired Student t-test according to Snedecor and Cochrn (1989).

\section{Results}

\section{1-Haematological Parameters:}

Figure (1) in the present study summarized the effect of irradiation and / or silymarin administration on blood haemoglobin, haematocrit \%, total erythrocytic count and total leucocytic count. The figure illustrated that exposing rats to both doses (1Gy and 6 Gy) $\gamma$ - irradiation resulted in statistically significant $(\mathrm{P}<0.05-0.001)$ decrease in all the examined parameters except for the significant increase $(\mathrm{P}<0.001)$ in blood haematocrit \% recorded at 2 hours time interval as compared to control value. The most drastic decrease occurred at two weeks after the higher dose level (6 Gy). The oral administration with silymarin did not show any significant differences as compared to control group, except for the recorded decrease in $\mathrm{Ht} \%(-11.3$ $\%, \mathrm{P}<0.01)$ at $2 \mathrm{hrs}$ post administration and the decrease in total leucocytic count recorded after two weeks (- 9.8 $\%, \mathrm{P}<0.01)$. It's administration prior to irradiation significantly improved to a large extent $(\mathrm{P}<0.05-0.001)$ the decrements in all the measured parame ters induced by irradiation at both doses (1 and $6 \mathrm{~Gy}$ ).

\section{2- Biochemical Parameters:}

A- Lipid Peroxidation [Plasma Malondialdehyde (MDA)]:

The data obtained in the present study (Table 1) indicated that the exposure to irradiation showed a pronounced significant elevation began after 2 days at $1 \mathrm{~Gy}$ and after 2 hours at 6 Gy and reached its maximum level (about $52.5 \%$ from control value) after 2 weeks. No significant alterations in plasma MAD levels were observed after silymarin administration alone. While, when it administered one week prior to irradiation a significant reduction $(\mathrm{P}<$ 0.001 ) of MDA levels was noticed at all time intervals versus control value and versus the irradiated group.

B- Blood glutathione content (GSH):

A dramatic and gradual significant decrease in GSH blood levels of group (2) exposed to both irradiation doses (1 Gy \& 6 Gy) was depicted in Table (1). Administration of silymarin for one week increased significantly blood GSH content at 2 hours (4.3\%), 2 days $(14.5 \%)$ and extended till 2 weeks (22.6\%) time interval as compared to control value. When it was adminis trated before irradiation $1 \mathrm{~Gy} \& 6 \mathrm{~Gy}$ it improved significantly the decrease in blood GSH levels induced by irradiation even than the control level.

\section{C - Liver Function Indices (Plasma ALT, AST and Al Ph):}

Exposure of female rats to both dose levels (1Gy and 6 Gy) $\gamma$ irradiation induced statistically signify cant $(\mathrm{P}<0.001)$ elevation in ALT, AST and $\mathrm{Al} \mathrm{Ph}$ levels in plasma as a dose dependent manner when compared to control rats. The oral administration with silymarin showed a significant increase in ALT plasma level after 2 hours and 2 days. No significant changes were recorded in AST plasma levels, whereas, it significantly decree ased $\mathrm{Al} \mathrm{Ph}$ plasma level at $2 \mathrm{hr}$ time interval as compared to control level. Furthermore, silymarin administration prior to irradiation significantly ameliorated the increase induced by $\gamma$ irradiation (Table 2). 
D - Kidney Function Indices (Plasma Urea, Uric Acid and Creatinine Levels):

Exposure of rats to both doses $1 \mathrm{~Gy}$ \& 6 Gy $\gamma$-irradiation induced a gradual significant increase in plasma levels of urea, uric acid and creatinine at all time intervals in a dose dependent manner. Silymarin administration alone showed no significant changes on urea level in plasma at 2 hours and 2 days, but it significantly decreased it after 2 weeks than the control value. A similar significant decline was observed in plasma levels of uric acid and creatinine after 2 days and 2 weeks as compared to control levels. Administration of silymarin before irradiation showed a prophylactic effect since it significantly $(\mathrm{P}<0.001)$ improved the elevations in urea, uric acid and creatinine plasma levels induced by $\gamma$-irradiation as depicted in table 3 .

Table 1: Effect of Gamma Irradiation (1 Gy and 6 Gy) and Silymarin Oral Administration (10 mg / $100 \mathrm{~g} \mathrm{~b}$. wt.) on Plasma Levels of Malondialdehyde (MDA) and Blood Glutathione (GSH) in Female Albino Rats.

\begin{tabular}{|c|c|c|c|c|c|c|}
\hline \multirow{2}{*}{$\begin{array}{c}\text { Groups } \\
\text { Time } \\
\text { intervals }\end{array}$} & \multirow{2}{*}{$\begin{array}{l}\overline{0} \\
\dot{\Xi} \\
\dot{0}\end{array}$} & \multicolumn{2}{|c|}{ Irradiated } & \multirow{2}{*}{ Silymarin Admin. } & \multicolumn{2}{|c|}{ Sil. Admin. + Irrad. } \\
\hline & & $1 \mathrm{GY}$ & 6Gy & & 1 Gy & 6 Gy \\
\hline 2 hours & \multirow{3}{*}{ 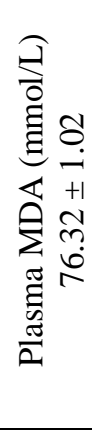 } & $73.36 \pm 1.04$ & $\begin{array}{c}87.92 \pm 0.87 \\
a^{* * *}, \mathrm{c}^{* * *} \\
\end{array}$ & $75.32 \pm 1.73$ & $\begin{array}{l}63.79 \pm 0.63 \\
a^{* * *}, d^{* * *}\end{array}$ & $\begin{array}{r}88.06 \pm 0.46 \\
a^{* * *}, c^{* * *}\end{array}$ \\
\hline 2 days & & $\begin{array}{l}84.86 \pm 1.17 \\
a^{* * *}, b^{* * *}\end{array}$ & $\begin{array}{c}108.7 \pm 5.01 \\
\mathrm{a}^{* * *}, \mathrm{~b}^{* *} \\
\mathrm{c}^{* *}\end{array}$ & $74.12 \pm 0.83$ & $\begin{array}{c}65.09 \pm 0.4 \\
a^{* * *}, d^{* * *}\end{array}$ & $\begin{array}{c}83.39 \pm 1.88 \\
a^{* * *}, b^{*} \\
c^{* * *}, d^{* * *}\end{array}$ \\
\hline 2 weeks & & $\begin{array}{l}94.59 \pm 1.4 \\
a^{* * *}, b^{* * *}\end{array}$ & $\begin{array}{c}116.54 \pm 2.64 \\
\mathrm{a}^{* * *}, \mathrm{~b}^{* * *}, \\
\mathrm{c}^{* * * *} \\
\end{array}$ & $73.39 \pm 0.90$ & $\begin{array}{c}68.72 \pm 1.11 \\
a^{* *}, b^{* *} \\
d^{* * *}\end{array}$ & $\begin{array}{c}93.52 \pm 1.27 \\
a^{* * *}, b^{*} \\
c^{* * *}, d^{* * *}\end{array}$ \\
\hline 2 hours & \multirow{3}{*}{ 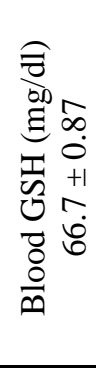 } & $\begin{array}{c}49.6 \pm 0.08 \\
\mathrm{a}^{* * *}\end{array}$ & $\begin{array}{l}37.39 \pm 0.62 \\
\mathrm{a}^{* * *}, \mathrm{c}^{* * * *}\end{array}$ & $\begin{array}{c}69.58 \pm 0.3 \\
\mathrm{a}^{*}\end{array}$ & $\begin{array}{l}52.01 \pm 0.24 \\
\mathrm{a}^{* * *}, \mathrm{~d}^{* * *}\end{array}$ & $\begin{array}{r}39.17 \pm 0.66 \\
a^{* * *}, c^{* * *}\end{array}$ \\
\hline 2 days & & $\begin{array}{l}46.68 \pm 1.1 \\
a^{* * *}\end{array}$ & $\begin{array}{c}26.94 \pm 1.2 \\
a^{* * *}, b^{* * *}, \\
c^{* * *}\end{array}$ & $\begin{array}{c}76.43 \pm 2.04 \\
a^{* *}, b^{*}\end{array}$ & $\begin{array}{c}48.85 \pm 0.56 \\
a^{* * *}, b^{* * *}\end{array}$ & $\begin{array}{c}36.37 \pm 0.6 \\
\mathrm{a}^{* * *}, \mathrm{~b}^{*}, \\
\mathrm{c}^{* * *}, \mathrm{~d}^{* * *} \\
\end{array}$ \\
\hline 2 weeks & & $\begin{array}{c}43.85 \pm 0.82 \\
a^{* * *}, b^{* *}\end{array}$ & $\begin{array}{l}23.58 \pm 0.95 \\
a^{* * *}, b^{* * *}, \\
c^{* * *}\end{array}$ & $\begin{array}{c}81.75 \pm 1.26 \\
a^{* * *}, b^{* * * *}\end{array}$ & $\begin{array}{l}46.56 \pm 0.48 \\
a^{* * *}, b^{* * *} \\
\mathrm{~d}^{*}\end{array}$ & $\begin{array}{c}35.63 \pm 0.41 \\
a^{* * *}, b^{* *} \\
c^{* * *}, d^{* * *}\end{array}$ \\
\hline
\end{tabular}

$\mathrm{a}=$ significantly different as compared with control group.

$\mathrm{b}=$ significantly different as compared with 2 hours time interval in the same group.

$\mathrm{c}=$ significantly different as compared with $1 \mathrm{~Gy}$ dose level at corresponding time interval within the same group.

$\mathrm{d}=$ significantly different as compared with corresponding time interval in irradiated group.

Each value represents mean $\pm \mathrm{SE}, \mathrm{n}=6, *_{-} * * *=\mathrm{P}<0.05-0.001$ 
Table 2: Effect of Gamma Irradiation (1 Gy and 6 Gy) and Silymarin Orally Administration (10 mg/100 g b. wt.) on Plasma Levels of ALT (U/L), AST (U/L) and Alkaline Phosphatase (U/L) in Female Albino Rats.

\begin{tabular}{|c|c|c|c|c|c|c|}
\hline "Groups & & \multicolumn{2}{|c|}{ Irradiated } & \multirow{2}{*}{$\begin{array}{l}\text { Silymarin } \\
\text { Admin. }\end{array}$} & \multicolumn{2}{|c|}{ Sil. Admin. + Irrad. } \\
\hline intervals & 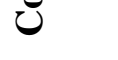 & $1 \mathrm{GY}$ & 6Gy & & 1 Gy & 6 Gy \\
\hline 2 hours & \multirow{3}{*}{ 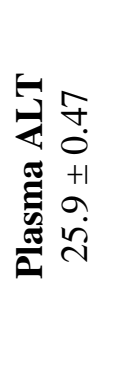 } & $\begin{array}{l}28.74 \pm 0.2 \\
a^{* * *}\end{array}$ & $\begin{array}{l}41.41 \pm 0.3 \\
a^{* * *}, c^{* * *}\end{array}$ & $\begin{array}{l}30.70 \pm 0.13 \\
a^{* * *}\end{array}$ & $\begin{array}{l}36.86 \pm 0.71 \\
a^{* * *}, d^{* * *}\end{array}$ & $\begin{array}{l}24.33 \pm 0.34 \\
a^{*}, c^{* * *}, d^{* * *}\end{array}$ \\
\hline 2 days & & $\begin{array}{l}30.26 \pm 0.53 \\
a^{* * *}, b^{*}\end{array}$ & $\begin{array}{c}49.29 \pm 0.76 \\
a^{* * *}, b^{* * *}, c^{* * *}\end{array}$ & $\begin{array}{l}30.06 \pm 0.17 \\
a^{* * *}, b^{*}\end{array}$ & $\begin{array}{l}37.27 \pm 0.21 \\
a^{* * *}, d^{* * *}\end{array}$ & $\begin{array}{l}24.68 \pm 0.27 \\
c^{* * *}, d^{* * *}\end{array}$ \\
\hline 2 weeks & & $\begin{array}{l}33.44 \pm 0.91 \\
a^{* * *}, b^{* *}\end{array}$ & $\begin{array}{c}50.27 \pm 0.23 \\
\mathrm{a}^{* * *}, \mathrm{~b}^{* * *}, \mathrm{c}^{* * *}\end{array}$ & $\begin{array}{l}25.43 \pm 0.22 \\
b^{* * *}\end{array}$ & $\begin{array}{l}27.81 \pm 0.3 \\
a^{* *}, b^{* * *}, d^{* * *}\end{array}$ & $\begin{array}{c}24.78 \pm 0.22 \\
\mathrm{c}^{* * *}, \mathrm{~d} * * *\end{array}$ \\
\hline 2 hours & \multirow{3}{*}{ 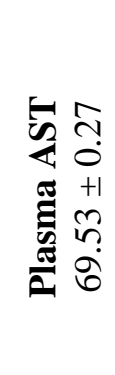 } & $\begin{array}{l}117.2 \pm 0.36 \\
a^{* * *}\end{array}$ & $\begin{array}{c}124.44 \pm 0.3 \\
\mathrm{a}^{* * *}, \mathrm{c}^{* * *}\end{array}$ & $69.42 \pm 0.25$ & $\begin{array}{l}72.79 \pm 0.41 \\
a^{* * *}, d^{* * *}\end{array}$ & $\begin{array}{r}98.1 \pm 1.27 \\
a^{* * *}, c^{* * *}, d^{* * *}\end{array}$ \\
\hline 2 days & & $\begin{array}{l}116.74 \pm 0.35 \\
a^{* * *}\end{array}$ & $\begin{array}{c}117.71 \pm 1.27 \\
a^{* * *}, b^{* * *}\end{array}$ & $69.88 \pm 0.18$ & $\begin{array}{l}71.99 \pm 0.46 \\
a^{* *, d * * * *}\end{array}$ & $\begin{array}{c}92.24 \pm 0.74 \\
\mathrm{a}^{* * *}, \mathrm{~b}^{* *} \\
\mathrm{c}^{* * *}, \mathrm{~d}^{* * *}\end{array}$ \\
\hline 2 weeks & & $\begin{array}{l}120.85 \pm 1.2 \\
a^{* * *}, b^{*}\end{array}$ & $\begin{array}{c}123.39 \pm .53 \\
\mathrm{a}^{* * *}\end{array}$ & $69.83 \pm 0.46$ & $\begin{array}{l}71.4 \pm 0.59 \\
a^{* * *}, d^{*}\end{array}$ & $\begin{array}{r}93.74 \pm 0.78 \\
a^{* * *}, c^{* *}, d^{* * *}\end{array}$ \\
\hline 2 hours & \multirow{3}{*}{ 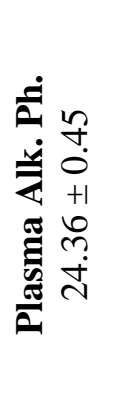 } & $27.15 \pm 2.27$ & $\begin{array}{l}33.08 \pm 1.06 \\
\mathrm{a}^{* * *}, \mathrm{c}^{*}\end{array}$ & $\begin{array}{l}20.18 \pm 1.09 \\
a^{* *}\end{array}$ & $\begin{array}{l}37.3 \pm 2.05 \\
a^{* * *}, d^{*}\end{array}$ & $\begin{array}{l}24.69 \pm 1.24 \\
\mathrm{c}^{* * *}, \mathrm{~d}^{* * *}\end{array}$ \\
\hline 2 days & & $\begin{array}{l}59.53 \pm 1.06 \\
a^{* * *}, b^{* * *}\end{array}$ & $\begin{array}{r}37.08 \pm 1.23 \\
a^{* * *}, b^{*}, c^{* * *}\end{array}$ & $\begin{array}{l}25.74 \pm 1.8 \\
b^{*}\end{array}$ & $\begin{array}{l}44.09 \pm 3.84 \\
a^{* * *}, d^{*}\end{array}$ & $\begin{array}{c}19.63 \pm 0.36 \\
\mathrm{a}^{* * *}, \mathrm{~b}^{* *} \\
\mathrm{c}^{* * *}, \mathrm{~d}^{* * *}\end{array}$ \\
\hline 2 weeks & & $\begin{array}{l}48.36 \pm 1.23 \\
a^{* * *}, b^{* * *}\end{array}$ & $\begin{array}{l}27.27 \pm 0.99 \\
a^{*}, b^{* *}, c^{* * *}\end{array}$ & $\begin{array}{l}26.36 \pm 2.03 \\
b^{*}\end{array}$ & $\begin{array}{l}54.36 \pm 1.01 \\
a^{* * *}, b^{* * *}, d^{* *}\end{array}$ & $\begin{array}{c}24.36 \pm 0.93 \\
\mathrm{c}^{* * *}\end{array}$ \\
\hline
\end{tabular}

$\mathrm{a}=$ significantly different as compared with control group.

$\mathrm{b}=$ significantly different as compared with 2 hours time interval in the same group.

$\mathrm{c}=$ significantly different as compared with $1 \mathrm{~Gy}$ dose level at corresponding time interval within the same group.

$\mathrm{d}=$ significantly different as compared with corresponding time interval in irradiated group.

Each value represents mean $\pm \mathrm{SE}, \mathrm{n}=6, *_{-}^{*} * * * \mathrm{P}<0.05-0.001$ 
Table 3: Effect of Gamma Irradiation (1 Gy and 6 Gy) and Silymarin Orally Administration (10 mg / $100 \mathrm{~g}$ b. wt.) on Plasma Levels of Urea (mg / dl), Uric acid (mg / dl) and Creatinine (mg / dl) in Female Albino Rats.

\begin{tabular}{|c|c|c|c|c|c|}
\hline $\begin{array}{l}\text { Groups } \\
\text { Time } \\
\text { intervals }\end{array}$ & 它 & $1 \mathrm{GY}$ & liated & $\begin{array}{l}\text { Silymarin } \\
\text { Admin. }\end{array}$ & $\begin{array}{l}\text { Sil. Admin. + Irrad. } \\
1 \mathrm{~Gy} \quad 6 \mathrm{~Gy}\end{array}$ \\
\hline 2 hours & \multirow{3}{*}{ 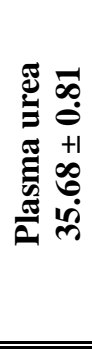 } & $38.42 \pm 1.2$ & $\begin{array}{c}49.17 \pm 1.15 \\
\mathrm{a}^{* * *}, \mathrm{c}^{* * *}\end{array}$ & $35.73 \pm 0.49$ & $\begin{array}{c}47.17 \pm 1.28 \\
\mathrm{a}^{* * *}, \mathrm{c} * * *\end{array}$ \\
\hline 2 days & & $\begin{array}{l}41.13 \pm .45 \\
\mathrm{a}^{* * *}\end{array}$ & $\begin{array}{c}53.7 \pm 1.45 \\
\mathrm{a}^{* * *}, \mathrm{~b}^{*}, \mathrm{c}^{* * *} \\
\end{array}$ & $33.26 \pm 1.5$ & $\begin{array}{lc}40.05 \pm .005 & 49.28 \pm 1.04 \\
\mathrm{a}^{* * *}, \mathrm{~d}^{*} & \mathrm{a}^{* * *}, \mathrm{c}^{* * *}, \mathrm{~d}^{*}\end{array}$ \\
\hline 2 weeks & & $\begin{array}{l}46.94 \pm 0.19 \\
\mathrm{a}^{* * *}, \mathrm{~b}^{* * *} \\
\end{array}$ & $\begin{array}{r}57.33 \pm 0.66 \\
\mathrm{a}^{* * *}, \mathrm{~b}^{* * *}, \mathrm{c}^{* * *} \\
\end{array}$ & $\begin{array}{l}30.12 \pm 1.22 \\
\mathrm{a}^{* *}, \mathrm{~b}^{* *}\end{array}$ & $\begin{array}{lr}43.62 \pm 1.46 & 55.46 \pm 0.34 \\
\mathrm{a}^{* *}, \mathrm{~b}^{*} & \mathrm{a}^{* * *}, \mathrm{~b}^{* * *}, \mathrm{c}^{* * *}, \mathrm{~d}^{*} \\
\end{array}$ \\
\hline 2 hours & \multirow{3}{*}{ 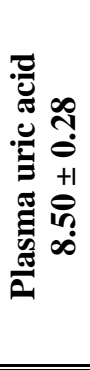 } & $\begin{array}{l}9.93 \pm 0.28 \\
a^{* *}\end{array}$ & $\begin{array}{c}18.10 \pm 0.34 \\
\mathrm{a}^{* * *}, \mathrm{c}^{* * *}\end{array}$ & $\begin{array}{l}10.01 \pm 0.31 \\
\mathrm{a}^{* *}\end{array}$ & $\begin{array}{lr}5.61 \pm 0.22 & 15.67 \pm 0.61 \\
\mathrm{a}^{* * *}, \mathrm{~d}^{* * *} & \mathrm{a}^{* * *}, \mathrm{c}^{* * *}, \mathrm{~d}^{* *}\end{array}$ \\
\hline 2 days & & $\begin{array}{l}19.39 \pm 0.29 \\
a^{* * *}, b^{* * *}\end{array}$ & $\begin{array}{c}28.8 \pm 0.54 \\
\mathrm{a} * * *, \mathrm{~b}^{* * *}, \mathrm{c} * * *\end{array}$ & $\begin{array}{l}7.70 \pm 0.18 \\
a^{*}, b^{* * *}\end{array}$ & $\begin{array}{c}17.61 \pm 0.41 \\
\mathrm{a}^{* * *}, \mathrm{~b} * * \\
\mathrm{c}^{* * *}, \mathrm{~d}^{* * *}\end{array}$ \\
\hline 2 weeks & & $\begin{array}{l}21.98 \pm 0.28 \\
\mathrm{a}^{* * *}, \mathrm{~b}^{* * *}\end{array}$ & $\begin{array}{c}32.16 \pm 0.34 \\
\mathrm{a} * * *, \mathrm{~b}^{* * *}, \mathrm{c} * * *\end{array}$ & $\begin{array}{l}5.76 \pm 0.23 \\
\mathrm{a}^{* * *}, \mathrm{~b}^{* * *}\end{array}$ & $\begin{array}{lc}6.41 \pm 0.21 & 18.75 \pm 0.27 \\
\mathrm{a}^{* * *}, \mathrm{~b}^{* *}, \mathrm{~d}^{* * *} & \mathrm{a}^{* * *}, \mathrm{~b}^{* *}, \\
& \mathrm{c}^{* * *}, \mathrm{~d}^{* * *} \\
\end{array}$ \\
\hline 2 hours & \multirow{3}{*}{ 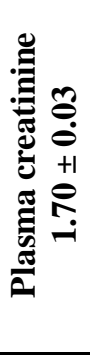 } & $1.76 \pm 0.08$ & $\begin{array}{r}3.23 \pm 0.01 \\
\mathrm{a}^{* * *}, \mathrm{c}^{* * *} \\
\end{array}$ & $1.75 \pm 0.05$ & $\begin{array}{lc}1.83 \pm 0.02 & \begin{array}{c}2.67 \pm 0.01 \\
\mathrm{a}^{* * *}, \mathrm{c}^{* * *}, \mathrm{~d}^{* * *}\end{array} \\
\mathrm{a}^{* *}\end{array}$ \\
\hline 2 days & & $\begin{array}{l}2.02 \pm 0.04 \\
\mathrm{a}^{* * *}, \mathrm{~b}^{* *} \\
\end{array}$ & $\begin{array}{r}3.28 \pm 0.04 \\
\mathrm{a}^{* * *}, \mathrm{~b}^{* * *}, \mathrm{c}^{* * *} \\
\end{array}$ & $\begin{array}{l}1.53 \pm 0.01 \\
\mathrm{a}^{* *}, \mathrm{~b}^{* *} \\
\end{array}$ & $\begin{array}{lc}2.02 \pm 0.01 & 2.82 \pm 0.01 \\
\mathrm{a}^{* * *}, \mathrm{~b}^{* * *} & \mathrm{a}^{* * *}, \mathrm{~b}^{* * *}, \mathrm{c}^{* * *}, \mathrm{~d}^{* * *} \\
\end{array}$ \\
\hline 2 weeks & & $\begin{array}{l}2.14 \pm 0.07 \\
\mathrm{a}^{* * *}, \mathrm{~b}^{* *}\end{array}$ & $\begin{array}{c}3.52 \pm 0.03 \\
\mathrm{a}^{* * *}, \mathrm{~b} * * *, \mathrm{c} * * *\end{array}$ & $\begin{array}{l}1.28 \pm 0.02 \\
\mathrm{a}^{* * *}, \mathrm{~b} * * *\end{array}$ & $\begin{array}{lc}1.84 \pm 0.09 & 3.04 \pm 0.02 \\
\mathrm{~d}^{*} & \mathrm{a}^{* * *}, \mathrm{~b}^{* * *}, \mathrm{c}^{* * *}, \mathrm{~d}^{* * *}\end{array}$ \\
\hline
\end{tabular}

$\mathrm{a}=$ significantly different as compared with control group.

$\mathrm{b}=$ significantly different as compared with 2 hours time interval in the same group.

$\mathrm{c}=$ significantly different as compared with $1 \mathrm{~Gy}$ dose level at corresponding time interval within the same group.

$\mathrm{d}=$ significantly different as compared with corresponding time interval in irradiated group.

Each value represents mean $\pm \mathrm{SE}, \mathrm{n}=6, *_{-} * * *=\mathrm{P}<0.05-0.001$ 

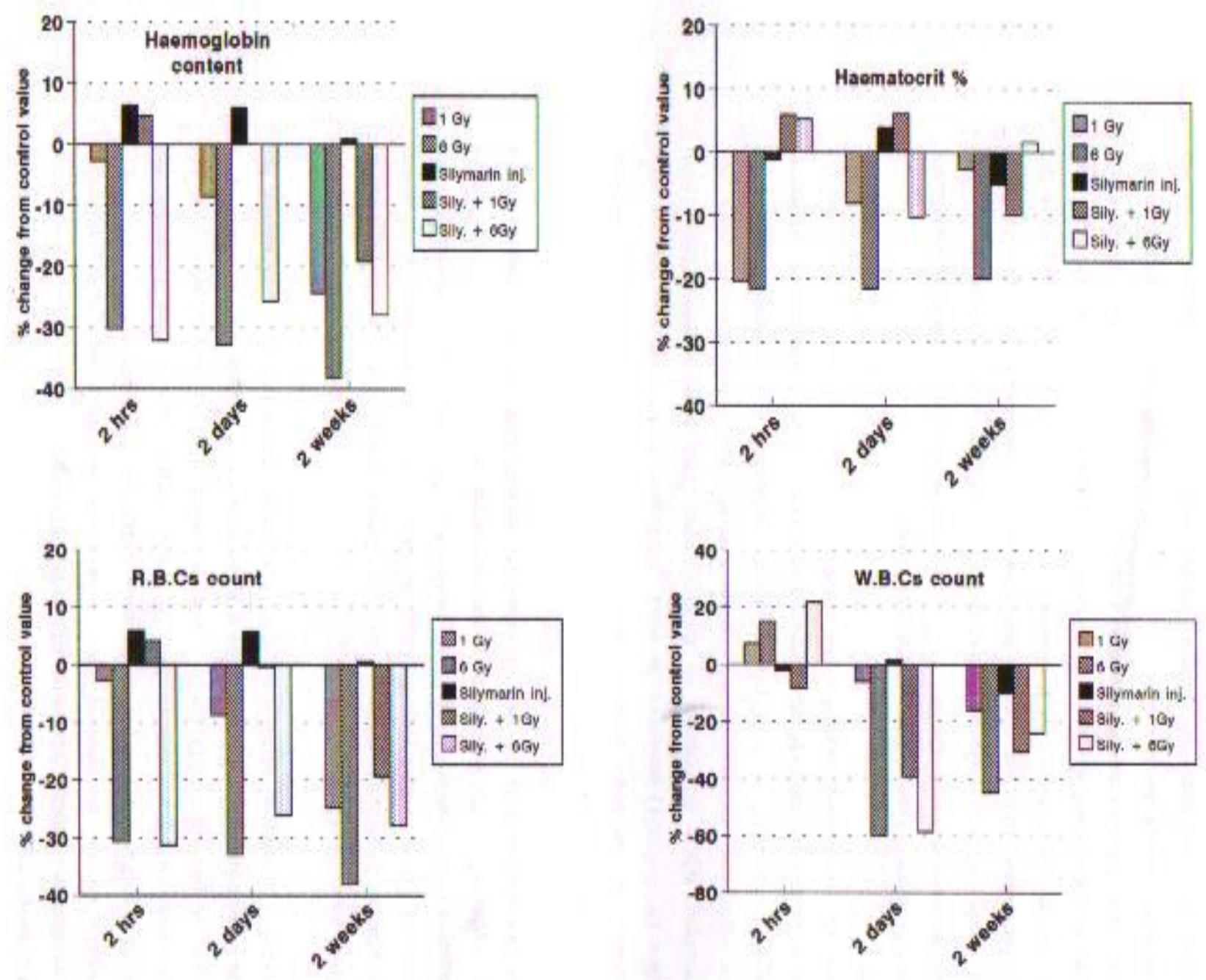

Figure 1: The percentage changes from control valuesof blood haemoglobin (g/dl), haematocrit \% RBCs $(10 \% \mathrm{~mm} 3)$ and WBCs $\left(10^{3} / \mathrm{mm} 3\right)$ count induced by gamma irradiation ( 1 Gy and 6 Gy) and silymarin orally administration (10 mg/100 gb. wt.)in female albino rats.

\section{Discussion}

Reults of the present study revealed that whole body $\gamma$-irradiation at $1 \mathrm{~Gy}$ and 6 Gy produced substantial disorders began as an early effect even at 2 hours post exposure and extended 2 weeks later. These were evident from the remarkable drop in all the examined haematological parameters $(\mathrm{Hg}, \mathrm{Ht} \%$, RBCs and WBCs count) which came in accord with the findings of several investigators (Tomatsu, 1992; Hassan et al, 1996 and Abou-Safi, 1998). The noticed decrease was exaggerated with the elapse of time (from $2 \mathrm{hr}$ to $2 \mathrm{wk}$ ) and with the high dose (6 Gy) rather than the relatively low dose (1Gy) as showed in figure 1. This could lead to the assumption that $\gamma$ - irradiation effect is a time and dose-dependent. This assumption confirmed the findings of Kim et al. (1998) who reported that mice irradiated at the dose 8 Gy 
exhibited time-related decreases in the WBCs, RBCs and platelet counts with maximal reduction noted at day 10 .

The recorded drop in haemoglobin concentration that reached $-38.1 \%$ of change as compared to control level two weeks after exposure to 6 Gy could be related to haemorrhagic effects of $\gamma$-rays (Meky et al., 1994). The most expressed drop in RBCs count (about $38.09 \%$ of change from control value) as recorded two weeks after 6 Gy $\gamma$-irradiation could be explained by: a- increased destru ction of mature erythrocytes (Roushdy et al., 1979); b- diminished ability of blood forming organs to produce their cells; c- thrombogenesis damage (Hassan et al., 1994); d- increased permeability of erythroid cells membrane in the hemolytic process and the erythrocyte membrane stability (Nikishkin et al., 1992). All these factors could be reasonable for the decrease in both RBCs and Hct value, in addition to the possible effect of irradiation on the circulating level of erythropoetin either directly or indirectly as a result of the renal failure or the impairment in the kidney function recorded in the study.

The observed decline in the total leucocytic count after gamma irradia tion exposure runs in full agreement with Roushdy and Ashry (1979), Tomatsu (1992) and Hassan et al. (1996). This decline could be attributed to: 1- a decrease in lymphocytes and neutrophils (Moss et al., 1979); 2mitotic inhibition of the bone marrow precursors (Abdel-Rahman, 1985); 3hypocellularity in hemopoietic stem cells and the function of stromal cells (Qing-Xi et al., 1989).

The obtained results showed that exposing rats to the two dose levels (1Gy \& 6 Gy) produced high levels of plasma malondialdehyde accompanied by a remarkable reduction in blood glutathione content monitoring the extent of the biological damage induced by irradiation represented by increased lipid peroxidation and depression of the antioxidant system. These results come in good accordance with many previous findings (Seino and Noritaka, 1995; Abu-Ghadeer et al., 1999; Saada et al., 1999 and Ibrahim, 2001). An evidence was provided (Gatske et al., 1990) that the decrease of antioxidant enzyme activities and the increase in free radicals may be the main cause of irradiation induced peroxidation, damage of cell activities and disorders in bio-oxidases activities (Zheng et al., 1996). Moreover, it was reported by Vladimirov (1998) that after radiation exposure, the predominant free radicals showed imbalance with the antioxidant system which became inactivated leading to the formation of lipid perox idation. Recently, Abou-Safi and Ashry (2003) recorded that whole body single (9 Gy) and fractionated (1.5 Gy x 6) $\gamma$ irradiation agigated marked oxidative stress represented by significant increase in MDA concomitant with a reduction in GSH content of both plasma and RBCs.

Whole body $\gamma$-irradiation in this study resulted in significant increments in plasma ALT, AST and alkaline phosphatase. These findings run in full agreement with previous ones (Geraci et al., 1993; Donnadieu-Claraz et al., 1999; Abou-safi, 1998 and AbdelFattah et al., 1999). These increments in plasma enzymes reflected clearly the lesions occurred in liver function after its cellular damage and consequently the elaboration of its intracellular enzymes into the blood stream (Hassan et al., 1994). These recorded elevations could be also due to a hypoxia state in the parenchymal liver cells and increased permeability of cell membrane (Ghanem, 1984) or 
mitochondrial membrane (Todorov and Daminov, 1985) causing the release of intracellular enzymes into circulation. Another explanation could be due to leakage of hydrolases from lysosomes and increasing of lysosomal enzyme activities in liver tissues (El-kashef et al., 1989 and Cornelissen \& Ridder, 1990). In addition, Geraci and Mariano (1996) recorded that the leakage of AST from liver slices in vitro correlated with the AST leakage from irradiated liver into the plasma in vivo, indicating hepatocyte membrane damage induced by irradiation. The destruction in liver cells also could refer to the increments in lipid peroxidation and the depression in antioxidant defense in liver cells. Relying on Oser (1979) that myocar dium, liver, kidney parenchyma and red blood cells are richer in transaminases than other body tissues. Alternatively, destruction and necrosis of any of these tissues lead to the release of large amounts of enzymes into the serum. This coincides with the decrease obtained in the studied haematological picture due to the destruction of cells induced by irradiation promoting the liberation of these enzymes with high levels in blood. The increase in liver enzymes, in the present study, was developed with the elapse of time, which came in accordance with Prasad (1984), who found that activation of lysosomal activity does not occur immediately after irradiation, but it develops progressively as a function of post irradiation time.

The current study depicted that $\gamma$ irradiation either at low dose level (1Gy) or at a sub-lethal one (6 Gy) induced significant increase in the plasma levels of the non-protein nitrogen compound represented by urea, uric acid and creatinine, as indices for kidney function. These results came similar to previous investigations by
EL-Kashef and Saada (1988) at the dose level 5.5 Gy, Konnova et al. (1991) at 8.5 Gy and Abou-Safi (1998) at 6 Gy dose level of $\gamma$-irradiation. These increments could be considered as a reflection of deteriorating renal performance (Geraci et al., 1990) due to the ammonia formed by deamination of amino acids in the liver which converted to urea (Ganong, 1999) or to increased breakdown of nucleic acids (Yarmonenko, 1988). Since irradiation may cause breaking of DNA molecules and destruction of their bases (the purines) which may be catabolized into uric acid (Ganong, 1999). As creatinine is formed largely in muscles and occurs freely in blood plasma and urine, its increased levels in plasma serve as an index of renal function impairment (Farag, 1994).

Silymarin has been clinically used largely as anti-hepatoxic agent due to its strong antioxidant activity (LahiriChatterjee et al., 1999). In the current work, silymarin was used to study its possible prophylactic role in confronting radiation hazard. It's administration twice daily for one week, with the last dose two hours before radiation exposure, induced amelior ation and even normalization of all the measured parameters extended to two weeks post irradiation. These results are well correlated to other findings (Hakova and Misurova, 1993, Kropacova et al., 1998 and Abu-Gadeer et al., 2001). Silymarin induced increases in patient serum levels of GSH, GSH-peroxidase and superoxide dismutase activity as recorded by Wellington and Jarvis (2001). The mechanisms of silymarin action could be attributed to different biochemical events such as the stimulation of the synthetic rate of ribosomal RNA (rRNA) species through stimulation of polymarase I and rRNA transcription, 
protecting the cell membrane from radical induced damage. It also influences certain metabolic processes including RNA synthesis and stabilizes cell membranes (Hakova et al., 1992). Its inhibitory effect in vivo on radiation, induced deactivation of enzymes and peroxidation of membrane lipids in rat liver microsomes (Gyorgy et al., 1992). The radioprotective effect of silymarin as a potent flavonoid may be attributed to the hydroxyl radical scavenging potency in a directed or an endogenous enzyme mediated manner (Shimoi et al., 1994).

Kropacova et al. (1998) examined the radioprotective and therapeutic effect of silymarin on development and repair of latent injury in rat liver by its application during the continual gamma irradiation (6 Gy / day or acute dose). It showed a curative effect especially after 14 days of its post radiation application. The therapeutic effect of silymarin as a hepatoprotective drug was investigated in rats after total body $\gamma$-irradiation with a dose of 6 Gy (Hakova and Misurova 1996). Recently, Wellington and Jarvis (2001), recorded that silymarin improved liver function indices (AST, ALT, gamma-glutamyl transferase and bilirubin) in patients with liver disease of various aetiology, including those exposed to toxic levels of toluene or xylene.

In the present study, female rats were examined daily for estrous cycle stages and selected at the estrous stage as the day suitable for exposure to whole body $\gamma$ - irradiation and blood sampling at 2 hours time interval followed by the meta-estrous and diestrous stages at which blood samples were taken at 2 days, as well as, after 2 weeks at the same stages. This choice depends on avoiding the pro-estrous stage preceding the estrous stage, at which the plasma estrogen reaches its maximum level in early afternoon (Stoklosowa and Szoltys, 1978), then a decrease is reported after $16.00 \mathrm{pm}$ (Shaikh, 1971), followed by gradual decrease till the estrus stage (De Hertogh 1973), at which ovulation occurs and enhanced the secretion of progesterone $\left(\mathrm{P}_{4}\right)$ i.e. the leutinization process. Yet, it was noticed from some epidemiologic observations that the highest incidence for tumorigenesis of mammary gland by irradiation arose in rats on diestrus in minimum level of ovarian hormones (Hirosh, 1992). Therefore, this choice came to produce the most possible protection with the minimum possible interference, since the study on female rats serves a great sector of women working in radiation application fields or those undergoing radiotherapy. Moreover, the study promotes the usage of silymarin as a useful protector against environmental stresses.

\section{References}

1. Abdel-Fattah, K. I., El-Sayed, N. M., Abou-Safi, H. M. and Hussein, A. H. (1999) The early alterations in some enzymatic activity, blood glucose and liver glycogen levels induced by atropine and whole body irradiation of rats. Egypt. J. Rad.Sci. Applic. 12 (2) :37.

2. Abdel-Rahman, N. A. (1985) Blood forming system as affected by irradiation and some new radioprotectors. M. Sc. Thesis, Univ. College for Women, Ain Shams Univ.

3. Abou-Safi, H., M. (1998) Haematological and physiological impairment of irradiation during estrus cycle in rats and role of combined treatment with vitamins A and B group. Egypt. J. Med. Sci. 19 (1): 157.

4. Abou-Safi, H., M. and Ashry, O. M. (2003) Modulation of radiation-induced disorders in plasma and red blood cells by vitamins $\mathrm{E}$, ascorbic acid and $\beta$ carotene combined treatment in female 
rats. Egypt. J. Rad. Sci. Applic. In Press.

5. Abu-Ghadeer, A. R. M., Osman, S. A. and Abbady, M. M. (1999) Garlic protects the glutathione redox cycle in irradiated rats. Egypt. J. Rad. Sci. Applic. 12 (2): 15.

6. Abu-Ghadeer, A. R. M.; Ali, S. E; Osman, S. A. A; Abu Bedair, F.A.; Abbady, M.M. and Kady, M. R. (2001) Antagonestic role of silymarin against cardiotoxicity and impaired antioxidant induced by adriamycin and/or radiation exposure in albino rats. Pakistan J. Biol. Sci. 4 (5): 604.

7. Bass, N. H. (1999) Is there any use for nontraditional or alternative therapies in patients with chronic liver disease? Cur. Gastroenterol. Rep. 1: 50.

8. Beutler, E.; Duron, O. and MikusKelly, B. (1963) Improved method for the determination of blood glutathione. J. Lab. Clin. Med. 61 (5): 882.

9. Cornelissen, M. and de Ridder, L. (1991) Dose- and time-dependent increase of lysosomal enzymes in embryonic cartilage in vitro after ionizing radiation. Scanning Microscopy 4 (3): 769.

10. Dacie, J. V. and Lewis, S. M. (1984) Practical haematology, 6th ed., Churchill Livingstone, Edinburgh, London, Melbourne and New York. p. 347.

11. De Hertogh, R. (1973) Dynamic studies of estrogen concentration in blood and tissues. In: Endocrinology, edited by: Scow, R. O. Expecta Medica / American Elsevier Publishing Co., N.Y. p. 857.

12. Donnadieu-Claraz, M., Benderitter, M., Joubert, C. and Voisin, P. (1999) Biochemical indicators of whole-body gamma radiation effects in the pig. Int.J. Radiat. Biol. 75 (2): 165.

13. El-Kashef, H. S. and Saada, H. N. (1988) Changes in the level of urea, creatine and creatinine in the liver and serum of irradiated rats. Isotope \& $\mathrm{Rad}$. Res. 20 (1): 43.

14. El-Kashef, H. S; Roushdy, H. M.; Saada, H. N. and Abd-Elsamie, M. (1989) Protection from radiation induced changes in liver and serum transaminases of whole body gamma irradiated rats. Egypt. J. Rad. Sci. Applic. 6 (2): 129.

15. Farag, M. H. (1994) Upgrading whole someness of soybeans through radiation deactivation of toxic lectin content. Egypt. J. Rad. Sci. Applic. 7 (1): 99.

16. Ganong, W. (1999) Review of medical physiology $19^{\text {th }}$ ed., Appleton \& Lange, California, USA, Chap. 17.

17. Gatske, G. G.; Mazhul, L. M.; Shablinskaya. O. V. and Volykhina, V. E. (1990) The influence of ionizing radiation on lipid peroxidation in rat in blood. Radiobiol. 30 (3): 413.

18. Geraci, J. P. Mariano, M.S. (1996) Radiation hepatology of the rat: Association of the production of prostacyclin with radiation induced hepatic fibrosis. Radiat. Res. 145: 93.

19. Geraci, J. P.; Jackson, K. L.; Mariano, M. S. and Michieli, B. M. (1990) Kidney and lung injury in irradiated rats protected from acute death by partial-body shielding. Rad. Res. 112: 95.

20. Geraci, J.P. Mariano, M.S. and Jackson, K. L. (1993) Radiation hepatology of the rat: Time dependent recovery. Radiat. Res.136 (2): 214.

21. Ghanem, A. M. F. (1984) Study of the histocompatibility antigens in relation to hepatic Shistosomiasis. M. D. Thesis, Faculty of Medicine, Alexandria Univ. Egypt.

22. Gyorgy, I., Antus, S., Blazovics, A. and Foldiak, G. (1992) Substituent effects in the free radical reactions of silybin: radiation-induced oxidation of the flavonoid at neutral $\mathrm{Ph}$. Int. J. Radiat. Biol. 16 (5): 603.

23. Hakova, H. and Misurova, E. (1993) The effect of silymarin and gamma radiation on nucleic acids in rat organs. J. Pharm. Pharmacol. 45 (10): 910.

24. Hakova, H. and Misurova, E. (1996) Therapeutical effect of silymarin on nucleic acids in the various organs of rats after radiation injury. Radiat. Biol. Radioecol. 36 (3): 365.

25. Hakova, N. Misurova, E. and Kropacova, K (1992) Effects of 
flavobion on nucleic acids in tissues of rats irradiated with gamma rays. Biull. Elesp. Biol. Med. 113 (3): 275.

26. Hassan, S. H. M.; Abu-Ghadeer, A. R. M.; Osman, S. A. A. and Roushdy, H. M. (1994) Possible role of the antipsychotic drug "fluphenazine" against post- irradiation injury in rats. Egypt. J. Rad. Sci. Applic. 7 (2): 181.

27. Hassan, S. H.; Abu-Ghadeer, A. R. and Osman, S. A. (1996) Vitamins B group and / or folic acid restoring the haematopoietic activity in irradiated rats. Egypt. J. Rad. Sci. Applic. 9 (1): 67.

28. Hirosh, I. (1992) Influence of endocrinological status at exposure on radiation induced mammary tumorigenesis of rats. In: Induction of radiation resistance. Biological and chemical means for radioprotection. By: Mikio, S. and Takeshi,Y. (eds), National Ins. of radiological Science., Chiba, Japan. p. 192.

29. Ibrahim, S. I. (2001) Biochemical studies on the control of aflatoxicosis in irradiated rats. MSc. Thesis, Fac. Sci., Ain Shams Univ.

30. Karbownik, . M and Reiter, R. J. (2000) Antioxidative effects of melatonin in protection aginst cellular damage caused by ionizing radiation. Proc.Soc.Exp. Biol. Med. 225 (1): 9.

31. Kim, S. G., Nam, S. Y. and Kim, C. W. (1998) In vitro radioprotective effects of altipraz in gamma-irradiated mice. Biochem. Pharmacol. 55 (10): 1585.

32. Konnova, l., Konnov, B. and Komar, V. (1991) Protein and amino acid metabolism at early periods following whole body uniform $\gamma$-and proton irradiation. Radiobiologya 31(3): 410.

33. Kropacova, K.; Misurova, E. and Hakva, H. (1998) Protective and therapeutic effect of silymarin on the development of latent liver damage. Radiat. Biol. Radioecol. 38 (4): 411.

34. Lahiri-Chatterjee, M., Katiyar, S. K., Mohan, R. R. and Agarwal, R. (1999) A flavonoid antioxidant, silymarin, affords exceptionally high protection against tumor promotion in the
SENCAR mouse skin tumorigenesis model. Cancer Res. 59: 622.

35. Meky, N. H.; Ezyat, I. E., El-Seifi, S. and Wakwak, M. M. (1994) Studies the effect of $\mathrm{CO}^{60}$ gamma irradiation on some haematological parameters in Japanase quails. J.Egypt. Ger. Soc. Zool. 13 (A): 29.

36. Moss, W.T., Brand, W. N. and Bellifora, H. (1979) In: The haematopoietic tissue. Rad. Con. $5^{\text {th }}$ ed. Toronto. London, P. 59.

37. Nikishkin, I. A.; Sukolinskij, V. N., Kovaleva, O. V.; Raspopova, N. I. and Naumenko, V. K. (1992) Enzyme of erythrocyte membrane protection under the combined effect of an antioxidant complex and acute irradiation. Radiobiologia 32: (5) 738.

38. Oser, B. L. (1979) Hawk's Physiological Chemistry. $14^{\text {th }}$ ed. Tata McGraw- Hill Pub. Comp. LTD. New Delhi, India.

39. Prasad, N. N. (1984) Handbook of radiobiology, CRC Press Inc., Boca Raton, Florida, USA, pp. 87.

40. Qing-Xi, Z., Gan-Yao,Y., Chu-Tse, W., Zhong- Xiong.T; Kang, W.; JiaPei, C. and Jie-Min, X.(1989) Meeting Report" International conference on biological effects of large dose ionizing and non- ionizing radiation. Int. J. Radiat. Biol. 55 (2): 307.

41. Quaglia, M. G., Bossu, E., Donati, E., Mazzanti, G. and Brandt, A. (1999) Determination of silymarin in the extract from the dried silybum marianum fruits by high performance liquid chromatography and capillary electrophoresis. J. Pharm. Biomed. Anal. 19 (3 - 4): 435.

42. Roushdy, H. M.; and Ashry, M. A. (1979) Haemopoeitic response to the interaction between protein malnutrition and gamma irradiation. Isot. Rad. Res. 11 (1): 19.

43. Roushdy, H. M.; Sallam, T. M. and Abdel-Salam, S. (1979) Studies of radiation induced hematological changes in rats. Isot. Rad. Res. 11 (1): 66.

44. Saada, H. N., Azab, Kh. Sh., Said, OZ., Mohamed, M.A., and Abbady, 
M. M. (1999) Role of genesing in the control of radiation induced injury in rat erythrocyte. J. Egypt. Ger. Soc. Zool., 28 (A): 191.

45. Seino, Z. and Noritaka, A. (1995) Radioprotection by dibyridamole in the aging mouse. Effect on lipid peroxidation in mouse liver, spleen and brain after whole body X-ray irradiation. Showa-Igakkai-Zasshi. 55 (1): 45.

46. Shaikh, A. A. (1971) Estrone and estrodiol levels in the ovarian venous blood during estrous cycle and pregnancy. Biol. Reprod. 5: 297.

47. Shimoi, K. Masuda, S., Furugori, M., Esaki, S. and Kinae, N. (1994) Radioprotective effect of antioxidative flavonoids in gamma-ray irradiated mice. Carcinogenesis, 15 (11): 2669.

48. Snedecor, G. W. and Cochrn, W. G. (1989) "Statistical Methods." $8^{\text {th }}$ ed., Louis State, University Press, USA.

49. Stoklosova, S. and Szoltys, M. (1978) Hormonal dynamics in the Preovulatory ovarian follicle and the oocyte in rat during proestrus. Ann. Biol. Anim. Bioch. Biophys. 18 (2B): 503.

50. Todorov, B. and Damianov, B. (1985) Biochemical and ultrastructural changes in liver of rats with a severe form of acute radiation sickness. Vet. Med. Nauki 22 (7): 62.

51. Tomatsu, (1992) Protective effect of catecholestrogens against Co ${ }^{60}$ gammaradiation injury in mice. Aichi- IkaDaigaku- Igakkai- Zasshi, 20 (1): 151.

52. Vladimirov, I. A. (1998) Free radicals and antioxidants. Vestn. Ross. Akad. Med. Nauk. 7: 43.

53. Wellington, K. and Jarvis, B. (2001) Silymarin: A review of its clinical properties in the management of hepatic disorders. Bio drugs, 15 (7): 465.

54. Yarmonenko, S. P. (1988) Radiosensitivity of tissues, organs, on organism. Radiation syndromes. In: "Radiobiology of humans and animals"; Mir Publishers, Moscow.

55. Yoshioka, T., Kawada, K., Shimada, T and Mori, M. (1979) Lipid peroxidation in maternal and cord blood and protective mechanism against activated-oxygen toxicity in the blood. Am. J. Obstet. Gynecol. 135: 372.

56. Zheng, H., Zhao, N., Zheng, R., Liu, $X$. and Chen, H. (1996) Effect of ionizing radiation on biooxidases activities in cytoplasm of mouse blood and liver cells. Chinese J. Radiobiol. Med. Protec. 16 (3): 179 . (3): 179. 


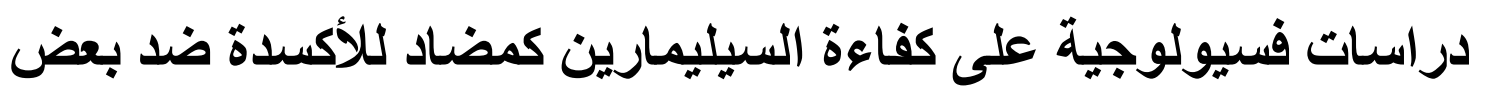

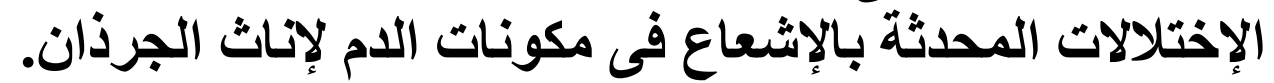

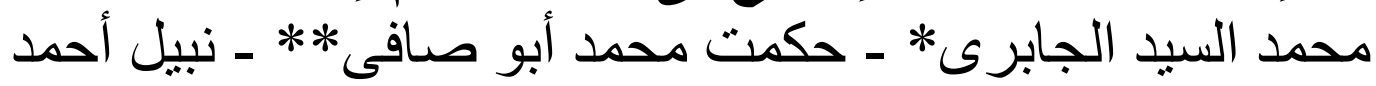

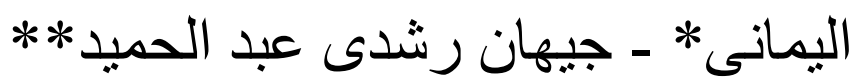

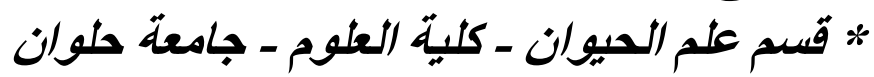

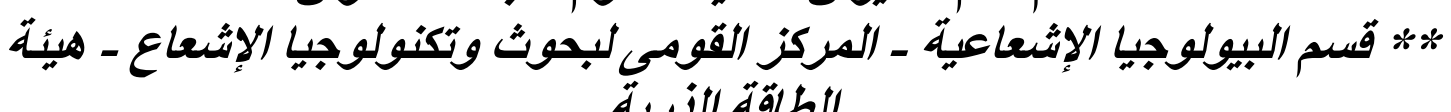
الطاقة الذرية المية

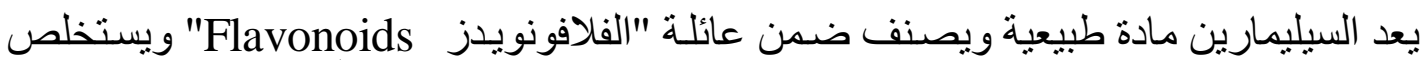

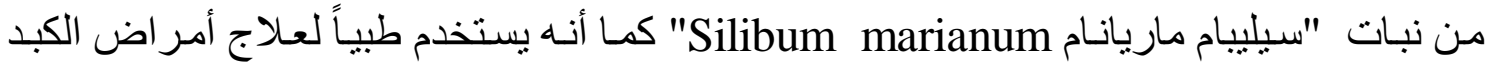

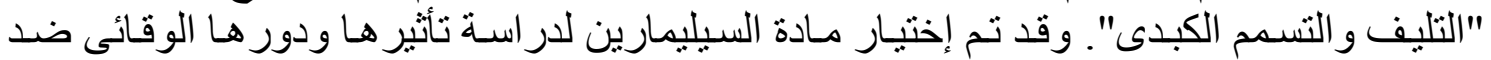

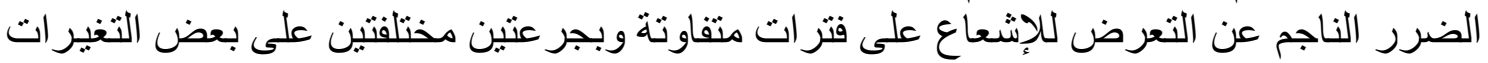
الفسيولوجية فى إناث الجرذان.

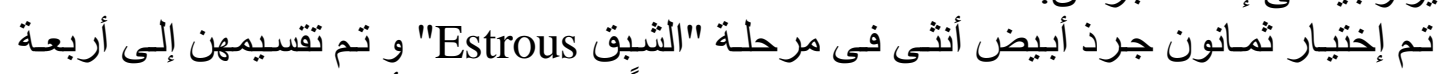

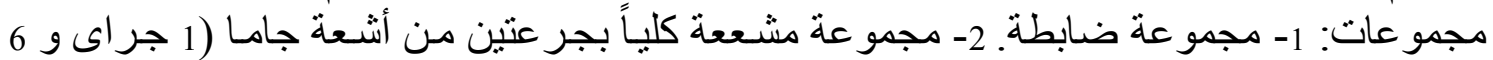

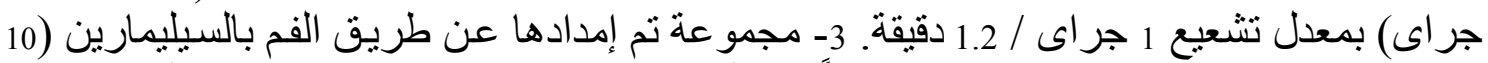

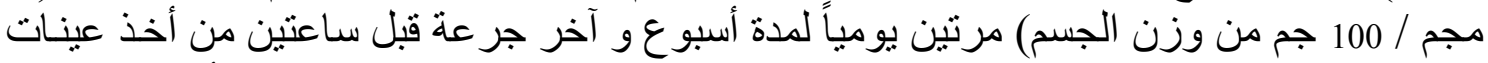

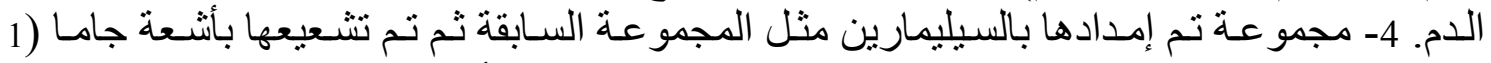

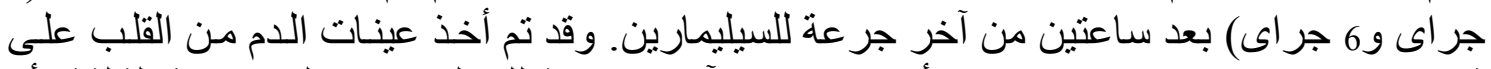

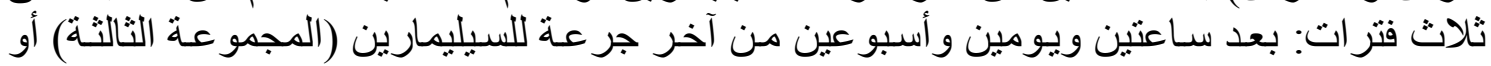

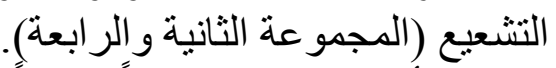

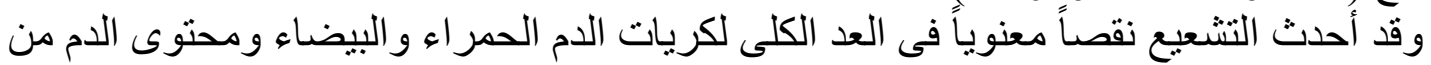

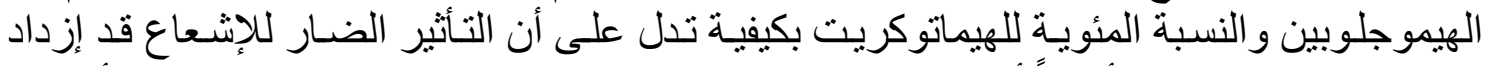

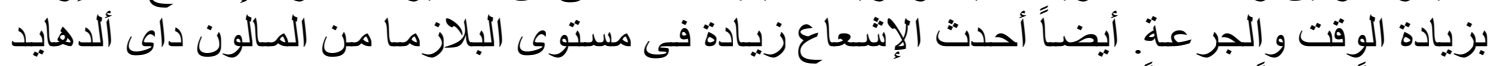

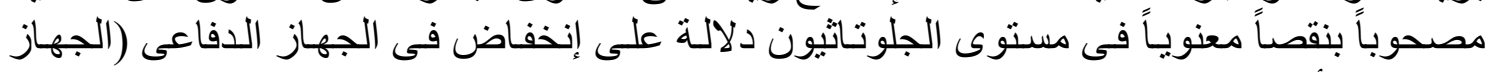

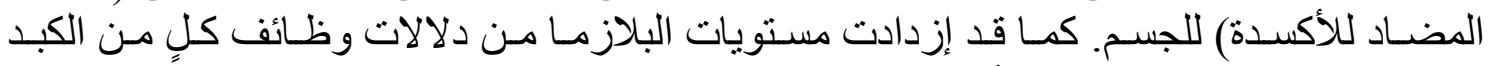

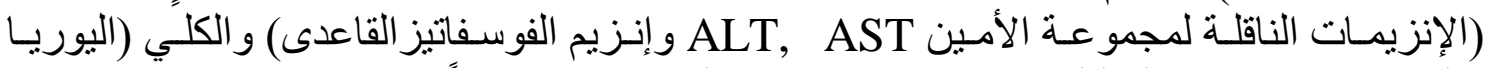
و الكرياتينين وحمض البوليك) زيادة معنوية مشيرة إلى حدوث إلى الختلاًاً فى وظائفهما.

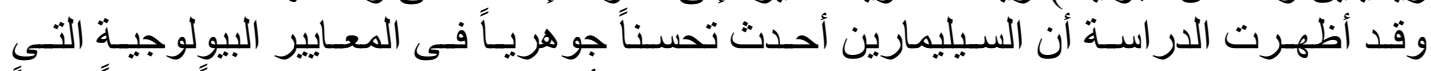

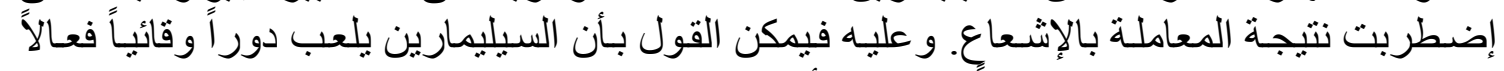
للإناث المتعرضات للإشعاع سو اءأ كعاملات أو متلقيات للعلاج بالإنشعاع. 